\title{
人体中多溴联苯醚(PBDEs)和全氟辛烷磺酰基化合物 (PFOS)研究进展
}

\author{
王亚䢂，江桂斌*
}

环境化学与生态毒理学国家重点实验室, 中国科学院生态环境研究中心, 北京 100085

*联系人, E-mail: gbjiang@rcees.ac.cn

2007-09-19 收稿, 2007-12-21 接受

中国科学院知识创新重要方向项目(批准号: KJCX2-YW-H04)和国家自然科学基金(批准号: 20737003, 20707033)资助

摘要 作为两大类新型持久性有机污染物(emerging chemicals), 多溴联苯醚(polybrominated diphenyl ethers, PBDEs) 和全氟辛烷磺酰基化合物 (perfluorooctane sulfonate, PFOS)所造成的污染已经成为全球性的环境问题. 对其污染问题的研究是 当前环境科学的热点之一. 本文对目前人体中 PBDEs 和 PFOS 研究的现状、进展以 及存在的问题进行了总结, 为我国开展这两类环境污染物的研究提供参考.
关键词

多溴联苯醚

全氟辛烷磺酰基化合物

母乳

血液

人体组织
多溴联苯醚 (polybrominated diphenyl ethers, PBDEs)属于溴代阻燃剂(brominated flame retardants, BFRs)的一种, 由于其优良的阻燃效率、热稳定性而 被广泛地应用于建材、纺织、化工、电子电器等行业. 近 10 年来全世界对 PBDEs 的需求量大幅增加, 我国 自 20 世纪 80 年代初以来, 十溴联苯醚已经成为国内 产量最大的含溴阻燃剂.

作为一种添加型的阻燃剂, 由于没有化学键的束 缚, PBDEs易于从产品中特别是在电子废品堆放及回 收利用过程中向环境中释放. 1981年在瑞典的梭鱼、鳗 鲡和海鳟中发现了 PBDEs的存在 ${ }^{[1]}$, 之后又在海鱼、贻 贝、底泥中检测到了 $\mathrm{PBDEs}^{[2]}$. 1987年, Jansson等人 ${ }^{[3]}$ 首次提出把PBDEs归结为一类全球性的环境污染物, 自此不断有报道从空气、水和人体中检出 PBDEs，并 且最近几年在世界范围环境中其含量呈快速上升趋势 [4 8]. 一个对瑞典母乳中POPs比较详细的调查显示, 母乳中其他POPs如多氯联苯从 20 世纪 70 年代至 90 年代呈减少趋势, 但是PBDEs含量一直处于递增趋势 [9]. 此后, 欧洲、北美、日本、中国等地区相继开展了 关于人体中PBDEs污染的研究.

全氟辛烷磺酰基化合物(perfloorooctane sulfonate, PFOS)是全氟化合物的代表物, 是一种重要的全氟化
表面活性剂, 自 20 世纪 60 年代以来, 已有上百种含 有磺酰基的产品被开发并获得大量应用. 由于其特 殊的化学性质, 被广泛地用于表面防污剂、泡沫灭火 剂、表面活性剂和特殊洗涤剂等 ${ }^{[10 ~ 13]}$. 该类产品的大 量使用使得其以各种途径进入到各种环境介质, 如 土壤、水体和大气中. 近年, 有关PFOS的环境行为、 毒性及污染现状的研究论文数量增长很快. 作为一 种新型持久性有机污染物, PFOS日益成为环境科学 所关注的热点.

\section{PBDEs 和 PFOS 的毒性及人体摄取途径}

\subsection{PBDEs 的毒性及人体摄取途径}

实验证明, PBDEs各单体由于溴取代个数的不同 而导致毒性差别较大. 商业产品中工业五溴联苯醚 毒性最大. 而八溴联苯醚会引起对胎儿的毒性和致 畸形. 对于十溴联苯醚对动物、人体健康影响的研究 始于 20 世纪 70 年代, 目前研究发现其在环境中具有 生物累积作用, 虽然目前研究证明, 十溴联苯醚并不 属于急性毒性物质, 但由于其在自然条件和生物体 内发生脱溴现象而降解为低溴代的联苯醚或其他溴 代有机物而使其毒性增大. 对老鼠和兔子的毒性研 究结果表明, PBDEs能够对神经系统产生损害, 并且 
对后代的甲状腺激素产生影响. Chen等人 ${ }^{[14]}$ 的研究 结果表明, PBDEs可以和芳香烃受体结合, 具有类似 于二恶英的致毒作用. 同时, PBDEs在制备、燃烧及高 温分解时会生成剧毒致癌物多溴二苯并二恶英 (polybrominated dibenzo-p-dioxin, PBDDs)及多溴二 苯并呋喃(polybrominated dibenzofuran, PBDFs) ${ }^{[15]}$ 而 对环境造成危害.

人体中PBDEs的来源主要有以下几个方面： 饮食摄入. PBDEs通过食物链的生物放大作用富集后 通过膉食进入人体，鱼类尤其是富含脂肪的鱼是最 主要的摄入源 ${ }^{[16]} ;$ (2) 母乳是婴儿摄入的主要来源, 许多报道都证实母乳中含量最高的BDE-47, 99和 153 可以通过母乳喂养而对儿童健康造成威胁 ${ }^{[17,18]}$; 呼吸摄入. 室内装饰材料、家具和电器中的PBDEs会 不同程度地散逸到空气中 ${ }^{[19]}$. 而人类则通过吸入空 气中的颗粒物而被动摄入PBDEs.

\subsection{PFOS 的毒性及人体摄取途径}

全氟辛烷磺酸(PFOA)急性毒性较低 ${ }^{[20]}$, 而PFOS 则属于中等毒性化合物, 经口短期大剂量暴露, 实验 动物出现明显的体重下降, 肝中毒症状甚至引发肌 肉震颤而导致死亡 ${ }^{[21]}$.

通过器官毒性研究表明, PFOA 和 PFOS 可以干
扰实验动物脂肪酸及与肝脏脂肪酸结合蛋白的结合 能力, 影响脂肪酸的代谢, 并且降低肝细胞各种酶的 活性 ${ }^{[22]}$. 对PFOA和PFOS其他的器官毒性研究证明, 此类物质可以使细胞内 $\mathrm{Ca}^{2+}$ 超载而引发神经毒性 ${ }^{[23]}$, 并对心肌产生损伤作用 ${ }^{[24]}$; 同时研究还表明PFOA和 PFOS可以影响胚胎发育并具有生殖毒性和遗传毒性 [25,26].

生物体内PFOS的来源和PBDEs的类似, 主要也是通 过食物摄取、呼吸或其他全氟化合物的生物降解 ${ }^{[10]}$.

\section{PBDEs 和 PFOS 在血液中的含量分布}

\subsection{PBDEs 在人体血液中的含量分布}

PBDEs除了通过食物摄取、呼吸等途径进入到人 体之外，通过老鼠试验已经证明BDE47 可以经真皮 吸收而进入体内, 而这也有可能是其进入人体的一 个途径 ${ }^{[27,28]}$. 在世界范围内, 大量的人体样品, 包括 人体组织、血样和母乳样品已经被采集并用于PBDEs 污染水平的调查. 图 1 显示了世界范围内人体血样 PBDEs主要单体BDE47, 99, 100, 153, 154 的含量分布 情况 ${ }^{[29 \sim 44]}$. 此图共包含了 10 个国家的 1157 个血样的 结果, 时间跨度从 1977 年到 2007 年. 从箱式图中可 以看出, BDE47 的含量最高, 其平均含量占

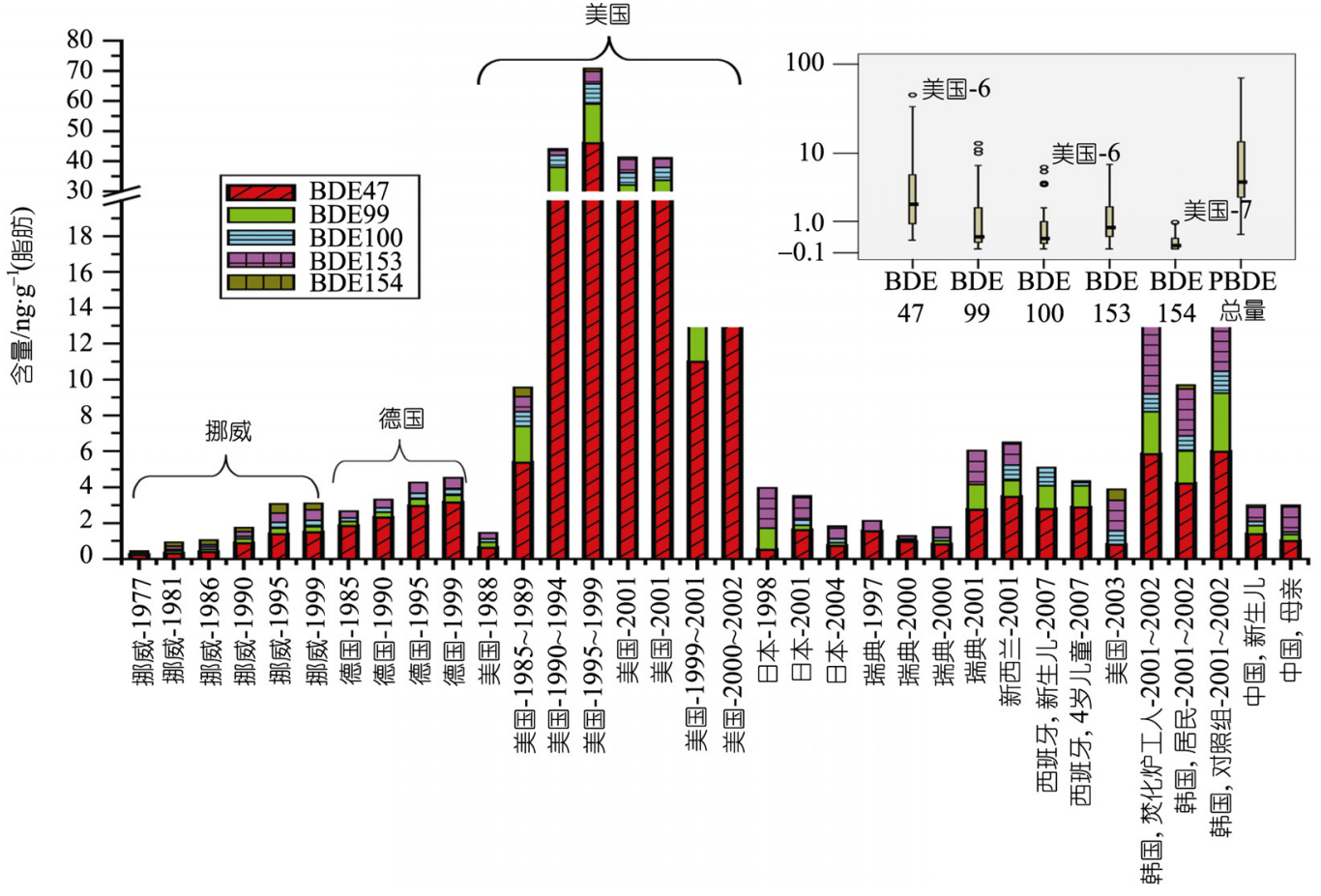

图 1 不同国家人体血样中 PBDEs 的含量分布图 其中美国-2001，瑞典-2000 数据引自不同文献. 插图为含量分布的箱式图 
PBDEs 总含量的 $47.9 \%$, 其次为 BDE153, 所占比例 为 $17.3 \%$.

从图中可以看出，不同地区人体血样中的 PBDEs 含量差别很大, 范围从 0.44 到 $71 \mathrm{ng} / \mathrm{g}$ (脂肪), 其中, 含量最高的为美国. 并且其他研究也已证明, 相对于欧洲, 美国人群处于一个相对较高的 PBDE 暴 露环境; 而日本人群所处的环境中, PBDE 的含量比 欧洲要低 ${ }^{[45]}$. 目前研究证明我国人体血样中PBDE 的含量还处于一个相对较低的水平.

一般认为, 在过去的 30 年中, 人体中 PBDE 的含 量已经增长了 100 倍左右. 其中最近几年美国人体 PBDE 的含量增加 10 倍左右, 而日本的增加量则在 5 倍左右. 图 1 显示挪威人体血样中的 PBDE 含量由 1977 年的 $0.44 \mathrm{ng} / \mathrm{g}$ 增加到 1999 年的 $3.1 \mathrm{ng} / \mathrm{g}$, 相对 应的德国的血样中 PBDE 的含量由 1985 年的 2.66 $\mathrm{ng} / \mathrm{g}$ 增加到 1999 年的 $4.53 \mathrm{ng} / \mathrm{g}$. 而美国的含量也同 样出现了快速增长的趋势.

由于主成分分析可以直观地将原始数据的基本 信息用二维图形表示出来, 为了进一步分析文献所 得到的数据, 我们对不同国家人体血样中的 PBDE 含 量数据进行了主成分分析, 分析结果由 SPSS 软件所 得. 在此次分析中, 只包括 BDE47, 99, 100, 153 和 154 的数据, 总共涉及到 34 组数据, 结果由图 2 显示, 前两个主成分共解释原始信息量的 $94 \%$. 从图 2 可以 看出, 美国人体血样中 PBDE 的含量和其他国家的结 果具有显著性差异(由于篇幅问题, 得分图并没有显 示在本文). 并且Sjödin等人 ${ }^{[41]}$ 的研究证明，从 1985

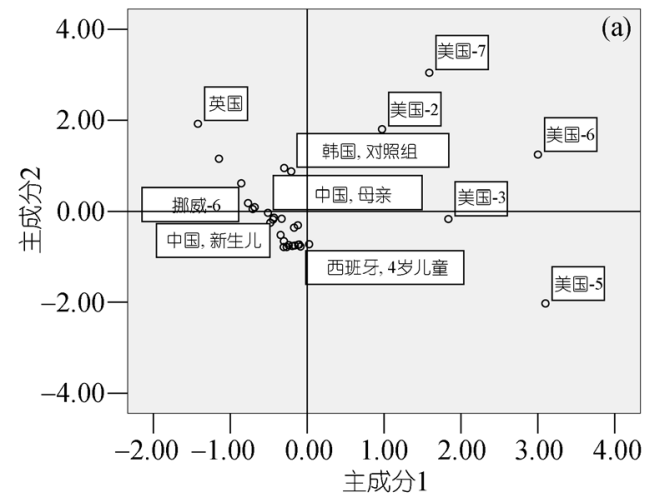

年到 2002 年期间，美国血样中 BDE47，99，100，153 和 PBDE 总量与时间呈线性增长的趋势. 由于美国 血样中 PBDEs 的含量要显著高于世界其他地区(图 1), 所以在做主成分分析时会掩盖其他的数据信息, 因此，我们把美国血样中 PBDE 含量的数据去除后 重新进行了主成分分析(图 2(b)). 结果显示, 在亚洲, 相对于日本和中国, 韩国人体血样中的含量要高于 这两个国家 ${ }^{[43]}$. 在此项工作中, 选取了垃圾焚烧厂 工人、当地居民和对照地区的人群作为研究对象. 结 果发现，并没有明显的证据证明垃圾焚烧厂工人血 样中 PBDE 的含量要比对照地区人群中的含量高. 他们认为, 垃圾焚烧并不是 PBDE 进入人体的一个 主要途径. 但是由于 PBDE 可以通过垃圾焚烧生成 毒性更大的溴代二恶英, 所以对 PBDE 在焚烧过程中 的转化以及对人体的影响也需要引起足够的重视. 而在英国, 血样中 BDE154 的含量要显著高于其他 地区.

\subsection{PFOS 和 PFOA 在人体血液中的含量分布}

PFOS 和 PFOA 是环境和生物体内两类主要的全 氟化合物. 最早的关于氟类有机物在人体血样中的 研究始于 20 世纪的 60 年代 ${ }^{[46]}$. 最近, 随着对氟类化合 物制造厂工人血液中 PFOS 和 PFOA 研究工作的开展, 全世界范围内人体血样中 PFOS 和 PFOA 的研究也在 不断地进行. 最近完成的成果包括对美国、哥伦比 亚、巴西、意大利、波兰、比利时、印度、马来西亚、 韩国、日本以及中国等人体血样中 PFOS 和 PFOA 以 及其他相关全氟化合物的研究 ${ }^{[47 \sim 49]}$. 表 1 列出了世界

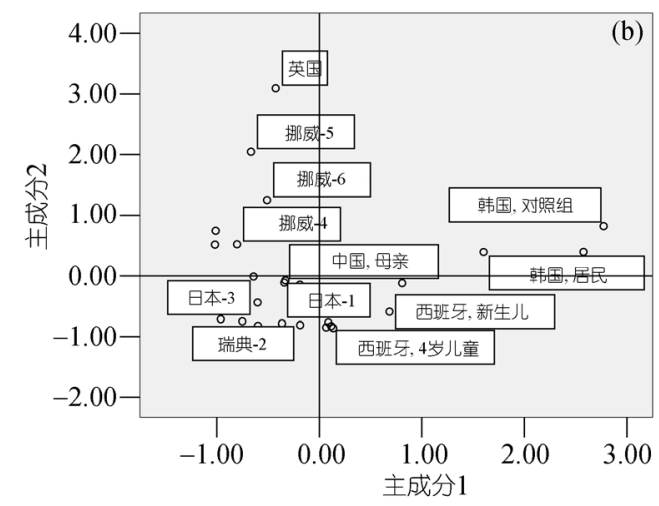

图 2 不同国家人体血样中 PBDE 含量的主成分分析结果

(a) 对于主成分 1, BDE47, 99, 100, 153 和 154 的载荷分别为: $0.918,0.909,0.880,0.545,0.328$; 对于主成分 2,5 个变量的载荷分别为: $0.378,0.392,0.459,0.731,0.908 ;$ (b) 去除美国数据后的主成分分析; 对于主成分 1, BDE47, 99, 100, 153 和 154 的载荷分别为: $0.943,0.945$, $0.900,0.802,0.072 ;$ 对于主成分 2,5 个变量的载荷分别为: $-0.063,-0.001,0.381,0.213,0.987$ 
表 1 世界各国人体血样中 PFOS 和 PFOA 的浓度分布 $(\mathrm{ng} / \mathrm{mL})$

\begin{tabular}{|c|c|c|c|c|c|c|c|}
\hline 国家 & 采样时间 & 样本数 & PFOS & 样本数 & PFOA & 基质 & 文献 \\
\hline 日本 & 2003 & 10 & 10.3 & & & 全血 & [50] \\
\hline 日本 & 2003 & 15 & 8.9 & 15 & nd & 全血 & [51] \\
\hline 日本 & 2003 & 15 & 2.9 & 15 & nd & 全血 & [51] \\
\hline 美国 & 2004 2005 & 17 & 68 & 12 & 535 & 全血 & [52] \\
\hline 美国 & $2004 \sim 2005$ & 299 & 4.9 & 299 & 1.6 & 全血 & [53] \\
\hline 美国 & $2001 \sim 2002$ & 57 & 24.2 & 57 & 4.26 & 全血 & [54] \\
\hline 波兰 & 2003 & & 21 & & 3.3 & 全血 & [55] \\
\hline 波兰 & 2003 & 25 & 42.14 & 25 & 20.5 & 全血 & [48] \\
\hline 西班牙 & 2006 & 48 & 7.64 & 48 & 1.8 & 全血 & [56] \\
\hline 瑞典 & $1997 \sim 2000$ & 66 & 66 & 66 & 2.4 & 全血 & [57] \\
\hline 中国 & 2004 & 85 & 52.7 & 85 & 1.59 & 全血 & [58] \\
\hline 哥伦比亚 & 2003 & 56 & 8.28 & 56 & 6.16 & 全血 & [48] \\
\hline 巴西 & 2003 & 27 & 11.74 & 27 & $<20$ & 全血 & [48] \\
\hline 比利时 & $1998 \sim 2000$ & 20 & 16.3 & 20 & 4.82 & 血浆 & [48] \\
\hline 马来西亚 & 2004 & 23 & 12.74 & 23 & 10 & 全血 & [48] \\
\hline 韩国 & 2003 & 50 & 21.2 & 50 & 61.8 & 全血 & [48] \\
\hline 美国 & 1974 & 178 & 29.5 & 127 & 2.3 & 血清 & [59] \\
\hline 美国 & 1989 & 178 & 34.7 & 177 & 5.6 & 血清 & [59] \\
\hline 美国 & $1990 \sim 2002$ & 23 & 31.1 & 23 & 11.6 & 血清 & [60] \\
\hline 美国 & $2000 \sim 2001$ & 645 & 34.9 & 645 & 4.6 & 血清 & [61] \\
\hline 美国 & 2003 & 20 & 55.8 & 22 & 4.89 & 血清 & {$[62]$} \\
\hline 美国 & $1999 \sim 2000$ & 238 & 31 & 238 & 4.2 & 血清 & [63] \\
\hline 美国 & $1999 \sim 2000$ & 1562 & 30.4 & 1562 & 5.2 & 血清 & [64] \\
\hline 美国 & 2004 2005 & 18 & 134 & 12 & 1046 & 血清 & [65] \\
\hline 意大利 & 2001 & 50 & 4.32 & 50 & $<3$ & 血清 & [48] \\
\hline 印度 & 2000 & 45 & 1.85 & 45 & 3.38 & 血清 & [48] \\
\hline 日本 & 2002 & 38 & 16.15 & 38 & 8.68 & 血清 & [48] \\
\hline 日本 & 2003 & 3 & 27 & - & - & 血清 & [48] \\
\hline 瑞典 & & 17 & 33.4 & - & - & 血浆 & [65] \\
\hline 澳大利亚 & & 40 & 23.4 & - & - & 血清 & [65] \\
\hline 英国 & & 13 & 14.2 & - & - & 血浆 & [65] \\
\hline 日本 & & 22 & 21.47 & 22 & 10.7 & 血清 & [66] \\
\hline
\end{tabular}

各国血样中全氟化合物研究的报道. 时间跨度从 1974 2005 年, 而 PFOS 和 PFOA 的浓度范围则随时 间和国家不同从低于检测限到每毫升上千纳克.

图 3 显示了全世界各地区的全血和血清中 PFOA 和PFOS以及日本和美国含量-时间趋势图. 从图中可 以看出，大部分国家血样中 PFOS 的含量要高于 PFOA的含量．总体上来讲，欧美国家的含量要高于 其他国家。从时间趋势来看，对于美国，全血中 PFOS 和 PFOA 从 1974 2000 年增长趋势不太明显, 而从2000 2005 年呈快速增长趋势. 而日本 2001 2004 年血样中这两个化合物的浓度含量变化不明显, 而是不同区域之间有较大差异. 其中最高值出现在 美国, Ehresman 等人采集了美国 3M公司(生产全氟类 化合物) 18 个员工的血样，对其中的全氟类化合物的 研究发现，血清中 PFOS 和 PFOA 的平均浓度为 134
和 $1046 \mathrm{ng} / \mathrm{mL}$ ，最高值则达到了 880 和 $7320 \mathrm{ng} / \mathrm{mL}$. 全血中两个化合物的浓度分别为 68 和 $535 \mathrm{ng} / \mathrm{mL}$. 他 们研究发现, 科研工作者体内这两类化合物的含量要 高于生产工人和管理工人体内的含量, 并且血清中和 血浆中这两类化合物的比例大致在 $1: 1^{[52]}$. 而对韩国 血清样品研究发现, PFOA 的含量要高于 PFOS 的含 量, 这说明在韩国某些地区存在着特定的暴露源 ${ }^{[48]}$.

\section{PBDEs 和 PFOS 在母乳中的含量分布}

母乳中的PBDEs 含量已经达到了人体内其他组 织中相同的浓度水平 ${ }^{[67]}$. 对于溴代阻燃剂的环境污 染关注正是始于一个对瑞典母亲乳汁中 POPs 比较详 细的调查 ${ }^{[9,68]}$. 同时, 相关综述也指出, 相对于 20 世 纪 70 年代, PBDEs 在母乳中的含量已经增加了 10 倍 左右并且BDE47 是最主要的单体 ${ }^{[69]}$. 
(a)

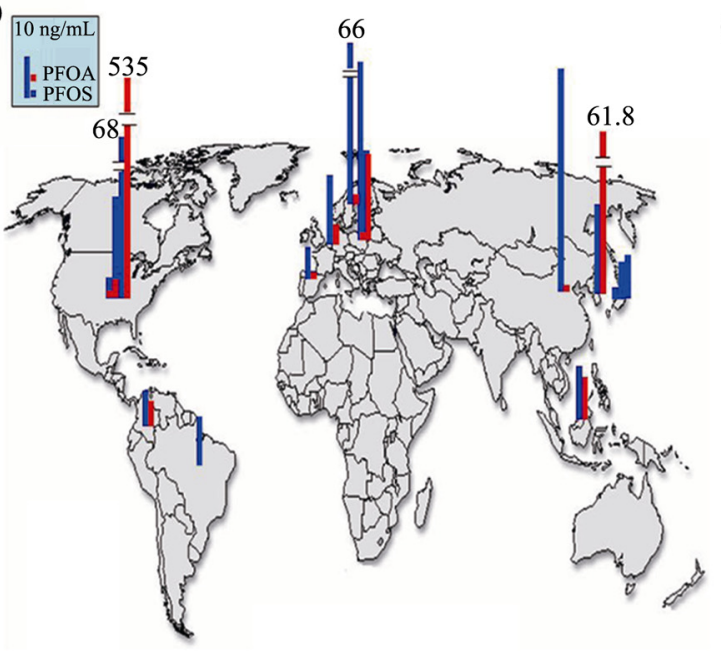

(b) $10 \mathrm{ng} / \mathrm{mL}$

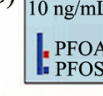

(c)
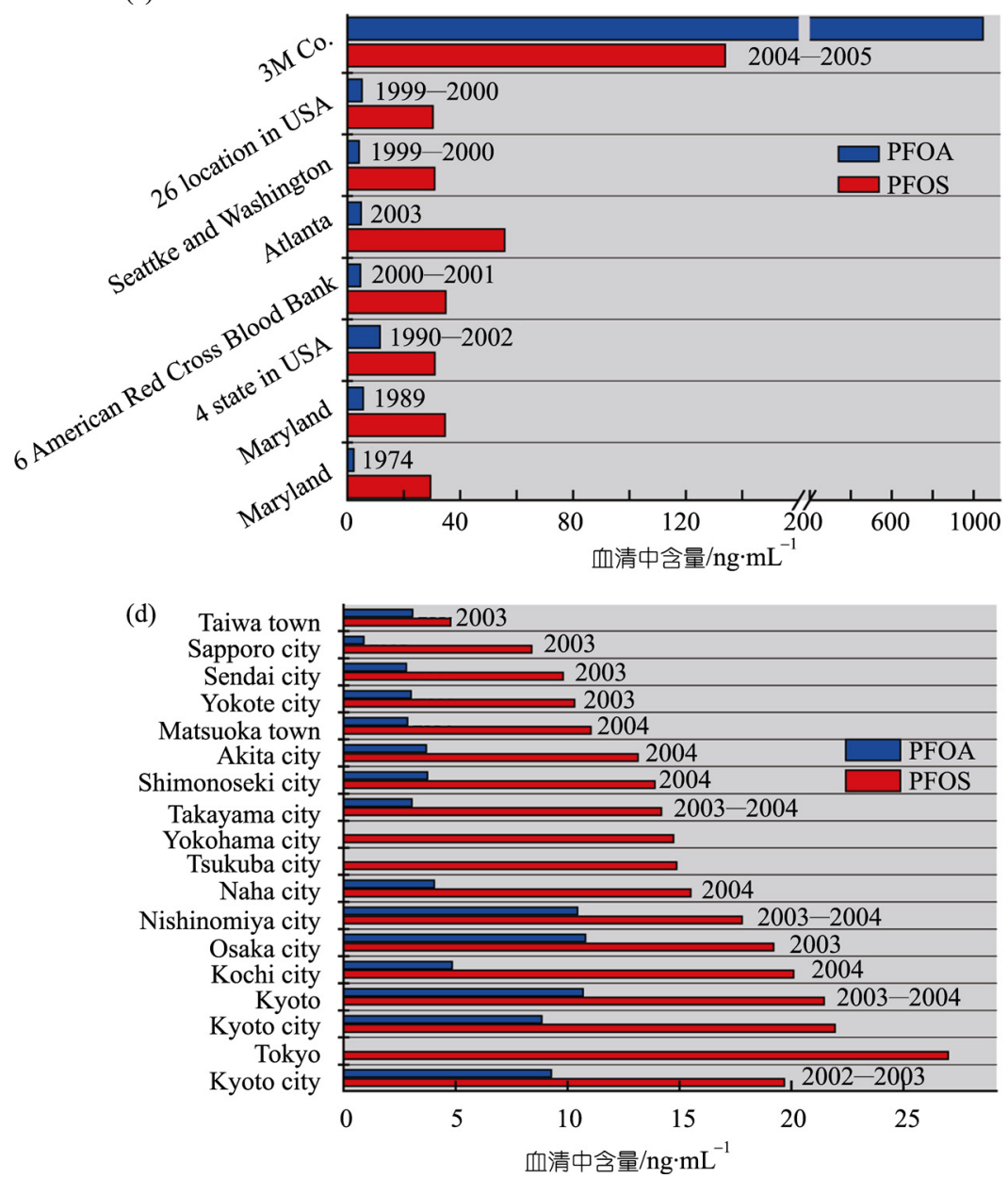

图 3 世界各地人体全血和血清中 PFOS 和 PFOA 的含量分布

(a) 全血中 PFOS 和 PFOA 的含量; (b) 血清中 PFOS 和 PFOA 的含量; (c)和(d)分别为美国和日本血清中含量-时间趋势图 
图 4 为不同国家母乳中PBDE含量分布的箱式图, 共包含了 22 个国家的 51 组数据 ${ }^{[28,70 \sim 95]}$. 和人体血样 中PBDE的含量分布类似，不同国家不同时期母乳中 PBDE的含量差别也比较大. PBDE总量在 0.07 384.6 $\mathrm{ng} / \mathrm{g}$ (脂肪)之间. 其中, BDE47 占到了总量的 $51.1 \%$, BDE153 则占了总量的 $18.1 \%$.

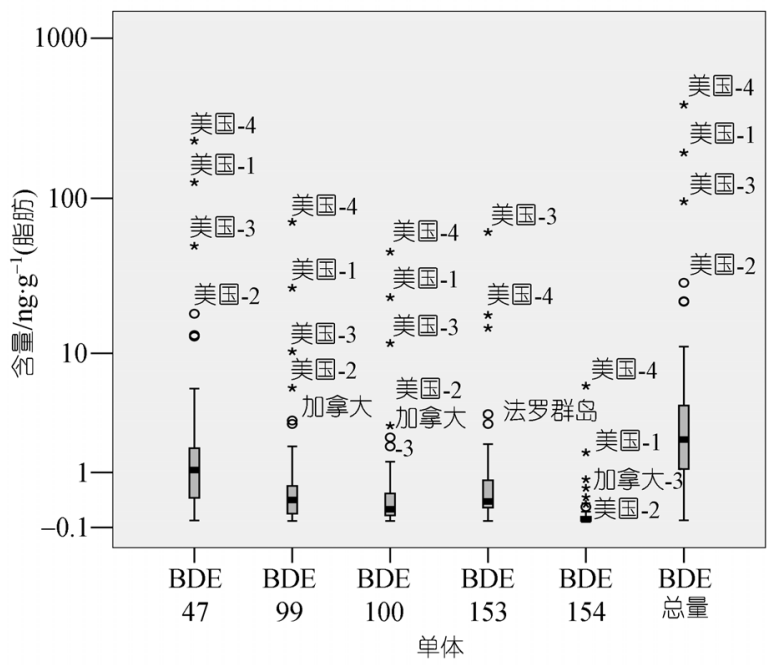

图 4 不同国家母乳中 PBDE 的含量箱式图

从图 4 可以明显看出, 母乳中PBDE含量处于较 高的地区包括美国和加拿大. 其中, 对美国太平洋西 部地区母乳中 PBDE 的研究发现, 对于某些样品, BDE153 的含量比BDE47 要高 ${ }^{[84]}$. 而在亚洲, 其含量 水平明显处于较低的水平. 相对于中国和日本, 韩国

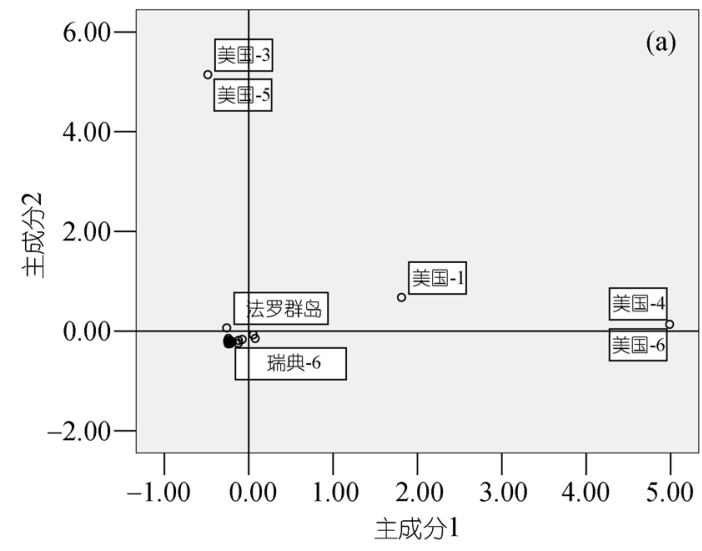

母乳中 PBDE 的含量并没有明显高于这两个国家，而 这一结果和血样中的含量不同. 用主成分分析对图 4 的数据进一步分析, 结果见图 5(a). 为了避免美国的 数据对其他国家的结果分析造成干扰, 我们将此部 分数据删除后又对其进行了主成分分析并示于图 5(b).

通过主成分分析的结果我们可以看到，美国母 乳样品中 PBDE 的含量处于最高水平, 其次为加拿大, 而欧洲地区, 除了英国处于较高的水平外, 其他国家 与亚洲国家的数据聚为一类, 母乳中 PBDE 的含量处 于相对较低的水平.

母乳中PFOS的研究相对较少. So等人 ${ }^{[96]}$ 报道了 在中国南方地区舟山采集的 19 个母乳样品中全氟化 合物的研究. 结果显示, 两个主要的全氟化合物 PFOS和PFOA在所有的样品中均有检出, 其含量分 别在 45 360 和 47 210 ng/L之间. 而母亲的年龄、体 重或儿童的体重与这两类化合物的含量并不存在显 著性相关, 但是每天摄入鱼的量与其他一些氟类化 合物在母乳中的含量呈正比.

Kärrman等人 ${ }^{[97]}$ 在采集了 1996 2004 年瑞典的母 乳样品后, 对其中的全氟类化合物进行了研究. 结果 发现, 有 5 种全氟化合物可以在母乳中检测到. 其中, 在所有的样品中都可以检测到 PFOS, 其含量平均为 相应的血样中的 $1 \%$, 并且和血样中的含量呈线性相 关, 而PFOA的检出率则相对较低. 通过对比不同年 代的样品含量, 并没有发现时间和含量的相关趋势.

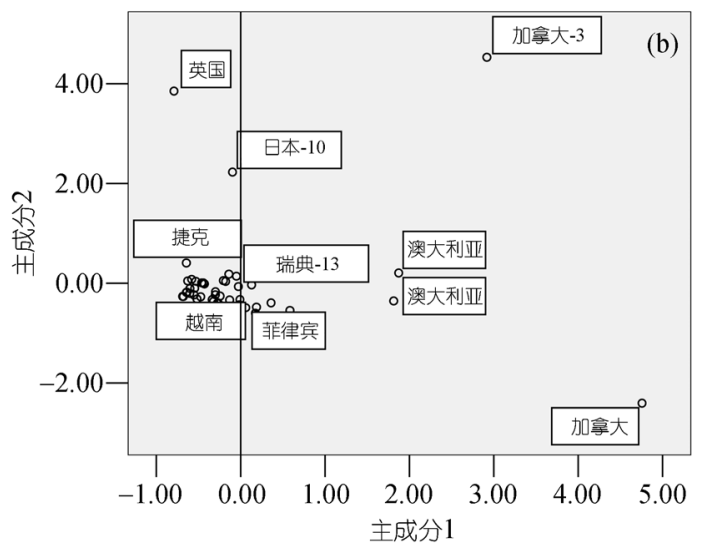

图 5 不同国家母乳中 PBDE 含量的主成分分析结果

(a) 对于主成分 1, BDE47, 99, 100, 153 和 154 的载荷分别为: $0.964,0.983,0.957,0.217,0.979$; 对于主成分 2,5 个变量的载荷分别为: $0.253,0.183,0.285,0.975,0.171$; (b) 去除美国数据后的主成分分析; 5 个变量的载荷对于主成分 1 分别为: $0.910,0.938,0.907,0.701$, 0.327 ; 对于主成分 2 分别为: $0.283,0.286,0.372,0.384,0.937$ 


\section{PBDEs 在人体组织中的含量分布}

人体组织中 PBDEs 的研究主要为脂肪组织中的 含量测定. 表 2 列出了亚洲、欧洲和北美洲的主要单 体的研究结果. 其含量随着时间和地区的不同差别 很大. BDE47 仍是最主要的单体, 其含量占了总量的 $43 \%$, 其次为 BDE153, 所占比例为总量的 $26.3 \%$.

亚洲的研究工作主要集中在日本和新加坡, 从表 2 可以看出, 从 20 世纪 70 年代到 2004 年, 日本人体组织 中 PBDEs 的含量从 $0.023 \mathrm{ng} / \mathrm{g}$ 增加到 $8.39 \mathrm{ng} / \mathrm{g}$, 增长速 度呈指数增长趋势. 新加坡的含量和日本的相当. 但是 新加坡人体组织中 PBDEs 的主要单体为 BDE47, 而 BDE99, 100, 153 和 154 的含量都低于检测限.

欧洲人体组织中 PBDEs 的含量和亚洲的水平相 当. 但是相对于亚洲地区，欧洲人体组织中 BDE99 的比例要处于较高水平. 并且在不同的时间段并没 有表现出很明显的浓度变化趋势.

人体组织中 PBDEs 浓度最高区域出现在美国, 其中 2003 2004 年的一项研究结果显示, 其人体中 PBDEs 的含量比上述两个地区高了两个数量级, 达 到了 $399 \mathrm{ng} / \mathrm{g}$, 同时也是 20 世纪 90 年代美国地区的 10 倍左右. 最高的一个样品甚至达到了 $9630 \mathrm{ng} / \mathrm{g}$, 这说明个体体内 PBDEs 的水平与其职业环境和暴露
环境有很大关系.

\section{PBDEs和PFOS含量与人体暴露环境的关系}

人体样品PBDEs和PFOS的含量与其所暴露的环 境明显相关. 对于一些暴露人群的研究发现, 包括血 样、母乳样品中的含量明显要比对照人群的高, 并且 BDE209 的检出率远远高于对照组人群. Qu等人 ${ }^{[111]}$ 采集了中国南方某电子垃圾拆卸地的拆卸工人、当地 居民和对照人群的血样, 对其中的PBDEs进行了研 究. 结果发现, 拆卸工人血样中PBDEs的含量比对照 组含量要高 10 20 倍, 其中BDE209 的含量最高达到 了 $3436 \mathrm{ng} / \mathrm{g}$ (脂肪), 是目前文献报道中含量最高的. 另外, 其他一些高溴代BDE如BDE197, 207, 208 等单 体也在拆卸工人血样中可以检出. 类似地, Thuresson 等人 ${ }^{[112]}$ 对生产或处理添加溴代阻燃剂的橡胶的工人 进行了追踪研究, 结果发现, 暴露于BDE209 环境中 的工人在体内除了检测出高含量的BDE209, 同时还 检测出了高含量的八溴和九溴联苯醚以及相对较低 含量的低溴化合物如BDE47, 100 等单体. 此结果同 时证明了BDE209 在人体体内存在脱溴现象. Thuresson等人 ${ }^{[113]}$ 追踪调查了电子垃圾拆卸工人在工作 条件改善之后PBDEs的变化情况. 虽然 2000 年货物 的处理量比 1997 年增加了两倍，但是由

表 2 不同国家人体组织中主要PBDEs单体含量 $(\mathrm{ng} / \mathrm{g} \text {, 脂肪 })^{\mathrm{a})}$

\begin{tabular}{|c|c|c|c|c|c|c|c|c|c|c|}
\hline 国家 & 类型 & 日期 & 样本数 & BDE47 & BDE99 & BDE100 & BDE153 & BDE154 & PBDEs & 文献 \\
\hline 日本 & 脂肪 & 1970 & 10 & 0.017 & 0.004 & 0.002 & & & 0.023 & [98] \\
\hline 日本 & 脂肪 & 2000 & 10 & 0.46 & 0.12 & 0.25 & 0.38 & 0.06 & 1.27 & [98] \\
\hline 日本 & 肝 & 2001 & 10 & 1.38 & 0.18 & 0.22 & 1.55 & 0.14 & 3.48 & [34] \\
\hline 日本 & 脂肪 & $2003 \sim 2004$ & 28 & 1.31 & 0.20 & 0.56 & 2.45 & 0.16 & 8.39 & [99] \\
\hline 新加坡 & 脂肪 & $2003 \sim 2004$ & 16 & 2.89 & nd & nd & nd & $\mathrm{nd}$ & 3.63 & [100] \\
\hline 比利时 & 脂肪 & 2000 & 20 & 1.45 & 0.28 & 0.48 & 2.49 & & 4.70 & [101] \\
\hline 比利时 & 脂肪 & $2001 \sim 2003$ & 53 & 0.88 & 0.47 & 0.72 & 2.40 & 0.93 & 5.40 & [101] \\
\hline 瑞典 & 脂肪 & 1994 & 5 & 2.37 & 1.29 & 0.29 & 0.96 & 0.06 & 4.97 & [102] \\
\hline 瑞典 & 脂肪 & 1994 & 1 & 8.80 & 1.10 & 1.80 & 1.70 & & 13.4 & [103] \\
\hline 芬兰 & 胎盘 & 1996 & 11 & 0.77 & 0.41 & & 0.40 & & 1.58 & [73] \\
\hline 芬兰 & 脂肪 & 1998 & 10 & 6.14 & 2.02 & & 2.18 & & 10.3 & [104] \\
\hline 芬兰 & 脂肪 & & 37 & 0.55 & 0.74 & na & 0.30 & na & 1.59 & [105] \\
\hline 西班牙 & 脂肪 & 1998 & 13 & 1.36 & 0.42 & 0.51 & 1.83 & & 4.12 & [106] \\
\hline 西班牙 & 脂肪 & 2003 & 20 & 0.63 & 0.24 & 0.20 & 1.30 & 0.034 & 2.40 & [107] \\
\hline 捷克 & 脂肪 & 2000 & 14 & 0.40 & 0.12 & 0.13 & 0.41 & 0.03 & 1.09 & [108] \\
\hline 捷克 & 脂肪 & 2000 & 10 & 1.18 & 0.34 & 0.59 & 0.52 & 0.06 & 2.69 & [108] \\
\hline 美国 & 胸部脂肪 & $1996 \sim 1998$ & 52 & 18.0 & 6.60 & 3.20 & 4.10 & 6.40 & 38.3 & [109] \\
\hline 美国 & 胸部脂肪 & 1997 & 22 & 18.3 & 6.59 & 3.17 & 4.09 & 6.40 & 38.6 & [109] \\
\hline 美国 & 脂肪 & $2003 \sim 2004$ & 52 & 132 & 74.4 & 67.7 & 91.8 & 8.30 & 399 & [110] \\
\hline
\end{tabular}

a) nd 表示未检出; na 表示未分析 
于通风等工作条件的改善，使得工人血样中高溴代的 $\mathrm{BDE}$ 含量呈显著降低趋势, 相对地, BDE47的含量并没 有明显变化. 他们认为是由于高溴代的 BDE 在人体内 具有较短的半衰期所导致.

人体PBDEs的主要来源也是目前PBDEs研究的一 个热点. Wu等人通过对美国马萨诸塞州母乳PBDEs与 相应母亲的饮食习惯、室内空气中PBDEs的关系进行研 究发现, 母乳中PBDEs的含量与每天肉类、脂肪的摄取 量显著相关，与鱼肉的消费正相关但并不显著. 同时， 母乳中PBDEs与室内灰尘中PBDEs的显著相关性也说 明了室内环境也是人体PBDEs 暴露的一个重要来源, 虽然目前还不是特别清楚具体的摄取途径 117$]$. 同时, 少量的证据证明素食饮食习惯的人体内的PBDEs也有 随时间逐渐降低的趋势 ${ }^{[114]}$. Meng等人 ${ }^{[115]}$ 进一步研究 了不同的膳食结构对不同年龄人群PBDEs摄取的影响. 通过对比发现, 通过呼吸途径摄取PBDEs, 婴儿的量要 远远高于其他年龄阶段的人群. 相对于世界其他地区, 中国地区所消费的鱼体内的PBDEs的含量处于一个较 低的水平, 并且通过鱼肉的消费摄取PBDEs的量要远 远低于世界其他地区，但是通过呼吸摄取的PBDEs要 比其他地方高.

通过食物摄取似平是全氟化合物进入人体的一个 主要途径. Falandysz等人 ${ }^{[55]}$ 在对波兰南部波罗的海地 区一个海湾区域的居民血样中全氟化合物的研究后发 现，除了PFOS和PFOA，还有 8 类全氟化合物可以在人 体富集. 并且通过对比鱼肉的摄取量, 他们发现摄取鱼 肉较多的人, 其体内全氟化合物的量要明显高于其
他人群.

\section{6 结论}

PBDEs和全氟类化合物作为新型持久性有机污染 物，已经在全球范围的各种环境介质中存在并对生态 系统造成了一定影响. 在过去几年中, 各国的研究工作 者已经投入了大量的精力和财力对其进行研究. 并且 各个国家已经出台了相应的措施限制或者禁止此两类 化合物的生产和使用，如欧盟已经禁止使用五溴和八 溴的产品，同时禁止含有此类化合物的产品进入欧盟 市场，而美国环境保护总署也制定了严格的管理规定 来对 PFOS 类化合物的生产和使用进行限制. 有关这两 类化合物在环境介质中的环境过程、迁移转化、对生态 系统的长期危害性、人体内累积此两类污染物的暴露 途径、以及长期毒理效应都需要进一步的研究. 对于我 国而言, 这两类化合物的研究还处于刚刚起步阶段, 但 是在过去几年对这两类化合物的研究特别是 PBDEs 的 研究已经有了长足的进步, 许多实验室包括卫生系统 已经开展相应的工作. 对于某些典型污染区域如电子 垃圾拆卸地人体暴露 PBDEs 的长期危害性和生态健康 风险评价已经开展. 但是到目前为止有关此两类化合 物的污染源、环境中迁移转化规律、污染区域的环境修 复以及其潜在的长期生态危害性还没有研究清楚. 对 于 PFOS 类物质, 快速准确的检测方法也是今后研究的 重点. 有关上述问题的工作成果将对我国评估这两类 化合物的使用和排放、环境生态损伤及健康影响, 并对 制定控制对策、解毒方案和相关法律法规提供依据.

\section{参考文献}

1 Andersson Ö, Blomkvist G. Polybrominated aromatic pollutants found in fish in Sweden. Chemosphere, 1981, 10: 1051—1060[DOI]

2 Watanabe I, Kashimoto T, Tatsukawa R. Polybrominated biphenyl ethers in marine fish, shellfish and river and marine sediments in Japan. Chemosphere, 1987, 16: 2389-2396[DOI]

3 Jansson B, Asplund L, Olsson M. Brominated flame rerardants-ubiquitous environmental pollutants? Chemosphere, 1987, 16: 23432349 [DOI]

4 Li A, Rockne K J, Sturchio N, et al. Polybrominated diphenyl ethers in the sediments of the Great Lakes. 4. Influencing factors, trends, and implications. Environ Sci Thehnol, 2006, 40: 7528-7534[DOI]

5 Rayne S, Ikonomou M G, Antcliffe B. Rapidly increasing polybrominated diphenyl ether concentrations in the Columbia River System from 1992 to 2000. Environ Sci Technol, 2003, 37: 2847-2854 [DOI]

6 Song W, Ford J C, Li A, et al. Polybrominated diphenyl ethers in the sediments of the Great Lakes 3 Lakes Ontario and Erie. Environ Sci Technol, 2005, 39: 5600-5605[DOI]

7 Kim B H, Ikonomou M G, Lee S J, et al. Concentrations of polybrominated diphenyl ethers, polychlorinated dibenzo-p-dioxins and dibenzofurans, and polychlorinated biphenyls in human blood samples from Korea. Sci Total Environ, 2005, 336: 45-56 [DOI]

8 Thomsen C, Lundanes E, Becher G. Brominated flame retardants in archived serum samples from Norway: A study on temporal 
trends and the role of age. Environ Sci Technol, 2002, 36: 1414-1418[DOI]

9 Sudaryanto A, Kajiwara N, Takahashi S, et al. Geographical distribution and accumulation features of PBDEs in human breast milk from Indonesia. Environ Pollut, 2007, 151: 130-138 [DOI]

10 郭睿, 蔡亚歧, 江桂斌, 等. 全氟辛烷磺酰基化合物(PFOS)的污染现状与研究趋势. 化学进展, 2006, 18: 808一813

11 Houde M, Martin J W, Letcher R J, et al. Biological monitoring of polyfluoroalkyl substances: A review. Environ Sci Technol, 2006, 40: 3463-3473[DOI]

12 Prevedouros K, Cousins I T, Buck R C, et al. Sources, fate and transport of perfluorocarboxylates. Environ Sci Technol, 2006, 40: 32-44 [DOI]

13 金一和，汤先伟，曹秀娟，等. 全球性全氟辛烷磺酰基化合物环境污染及其生物效应。自然杂志, 2002, 24: 344一348

14 Chen G, Konstantinov A D, Chittim B G, et al. Synthesis of polybrominated diphenyl ethers and their capacity to induce CYP1A by the Ah receptor mediated pathway. Environ Sci Technol, 2001, 35: 3749-3756[DOI]

15 Thoma H, Hauschulz G, Knorr E, et al. Polybrominated dibenzofurans (PBDF) and dibenzodioxins (PBDD) from the pyrolysis of neat brominated diphenylethers, biphenyls and plastic mixtures of these compounds. Chemosphere, 1987, 16: 277-285[DOI]

16 Lind Y, Aune M, Atuna S, et al. Food intake of the brominated flame retardants PBDEs and HBCD in Sweden. Organohalog Compd, 2002, 58: $181-184$

$17 \mathrm{Wu}$ N, Herrmann T, Paepke O, et al. Human exposure to PBDEs: Associations of PBDE burdens with food consumption and house concentrations. Environ Sci Technol, 2007, 41: 1584-1589[DOI]

18 Betts K S. A new record for PBDEs in people. Environ Sci Technol, 2005, 39: 296A

19 Knoth W, Mann W, Meyer R, et al. Polybrominated diphenylether in house dust. Organohalog Compd, 2002, 58: 213-216

20 Olson C T, Andersen M E. The acute toxicity of perfluomoctanoic and perfluoroectanoic acid in male rats and effects on tissue fatty acid. Toxicol Appl Pharmacol, 1983, 70: 362-372[DOI]

21 Haughom B, Spydevold O. The mechanism underlying the hypolipemic effect of perfluorooctanoic acid (PFOA), perfluorooctane sulphonic acid (PFOSA) and clofibric acid. Biochim Biophys Acta, 1992, 1128: 65-72

22 Luebker D J, Hansen K J, Bass N M, et al. Interactions of fluorochemicals with rat liver fatty acid-binding protein. Toxicology, 2002, 176: $175-185$ [DOI]

23 李莹, 金一和. 全氟辛磺酸对大鼠中枢神经系统谷氨酸含量的影响. 毒理学杂志, 2004, 18: 232-233

24 Harada K, Xu F, Ono K, et al. Effects of PFOS and PFOA on L-type $\mathrm{Ca}^{2+}$ currents in guinea-pig ventricular myocytes. Biochem Biophys Res Commun, 2005, 329: 487-494ㅁD]

25 Lau C, Thibodeaux J R, Hanson R G, et al. Effects of perfluorooctanoic acid exposure during pregnancy in the mouse. Toxicol Sci, 2006, 90: 510-518[DOD]

26 Guruge K S, Yeung L W, Yamanaka N, et al. Gene expression profiles in rat liver treated with pedluoronctanoie acid (PFOA). Toxicol Sci, 2006, 89: 93-107[DOI]

27 Staskal D F, Diliberto J J, DeVito M J, et al. Toxicokinetics of BDE 47 in female mice: Effect of dose, route of exposure, and time. Toxicol Sci, 2005, 83: 215-223[DOI]

28 Jones-Otazo H A, Clarke J P, Diamond M L, et al. Is house dust the missing exposure pathway for PBDEs? An analysis of the urban fate and human exposure to PBDEs. Environ Sci Technol, 2005, 39: 5121 - 5130 [DOI]

29 Meironyté D, Norén K, Bergman A. Analysis of polybrominated diphenyl ethers in Swedish human milk. A time-related trend study, 1972-1997. J Toxicol Environ Health, 1999, 58: 329-341 [DOI]

30 Schröter-Kermani C, Helm D, Herrmann T, et al. The German environmental specimen bank-application in trend monitoring of polybrominated diphenyl ethers in human blood. Organohalogen Compd, 2000, 47: 49—52

31 Sjödin A, Patterson D G, Bergman A. Concentrations and spatial variations of polybrominated diphenyl ethers and other organohalogen compounds in Great Lakes air. Environ Sci Technol, 2001, 35: 3830 - 3833[DOI]

32 Nagayama J, Tsuji H, Takasuga T. Comparison between brominated flame retardants and dioxins or organochlorine compounds in blood levels of Japanese adults. Organohalogen Compd, 2000, 48: 27-30

33 Meironyté Guvenius D, Aronsson A, Ekman-Ordeberg G, et al. Human prenatal and postnatal exposure to polybrominated diphenyl ethers, polychlorinated biphenyls, polychlorobiphenylols and pentachlorophenol. Environ Health Perspect, 2003, 111: 1235-1241

34 Hirai T, Furutani H, Myouren M, et al. Concentration of polybrominated diphenyl ethers (PBDEs) in the human bile in relation to those in the liver and blood. Organohalogen Compd, 2002, 58: 277-280

35 van Bavel B, Hardell L, Kitti A, et al. High levels of PBDE in 5\% of 220 blood samples from the Swedish population. Organohalogen Compd, 2002, 58: 161-164

36 Mazdai A, Dodder N G, Abernathy M P, et al. Polybrominated diphenyl ethers in maternal and fetal blood samples. Environ Health Perspect, 2003, 111: 1249-1252

37 Harrad S, Porter L. Concentrations of polybrominated diphenyl ethers in blood serum from New Zealand. Chemosphere, 2007, 66: 
$2019-2023 \underline{[\mathrm{DOI}]}$

38 Takasuga T, Senthilkumar K, Takemori H, et al. Impact of fermented brown rice with Aspergillus oryzae (FEBRA) intake and concentrations of polybrominated diphenylethers (PBDEs) in blood of humans from Japan. Chemosphere, 2004, 57: 795-811 [DOI]

39 Carrizo D, Grimalt J O. Influence of breastfeeding in the accumulation of polybromodiphenyl ethers during the first years of child growth. Environ Sci Technol, 2007, 41: 4907-4912[DOI]

40 Thomas G O, Wilkinson M, Hodson S, et al. Organohalogen chemicals in human blood from United Kingdom. Environ Pollut, 2006, 141: $30-41$ [DOI]

41 Sjödin A, Jones R, Focant J F, et al. Retrospective time-trend study of polybrominated diphenyl ether and polybrominated and polychlorinated biphenyl levels in human serum from the United States. Environ Health Perspect, 2004, 112: 654-658

42 Bradman A, Fenster L, Sjödin A, et al. Polybrominated diphenyl ether levels in the blood of pregnant women living in an agricultural community in California. Environ Health Perspect, 2007, 115: 71-74

43 Lee S J, Ikonomou M G, Park H, et al. Polybrominated diphenyl ethers in blood from Korean incinerator workers and general population. Chemosphere, 2007, 67: 489-497[DOI]

44 Bi X H, Qu W Y, Sheng G Y, et al. Polybrominated diphenyl ethers in South China maternal and fetal blood and breast milk. Environ Pollut, 2006, 144: 1024-1030 [DOI]

45 Hites R A. Polybrominated diphenyl ethers in the environment and in people: A meta-analysis of concentrations. Environ Sci Technol, 2004, 38: 945-956 [DOI]

46 Taves D R. Evidence that there are two forms of fluoride in human serum. Nature, 1968, 217: 1050-1051

47 Hansen K J, Clemen L A, Ellefson M E, et al. Compound-specific, quantitative characterization of organic fluorochemicals in biological matrices. Environ Sci Technol, 2001, 35: 766-770[1DOI]

48 Kannan K, Corsolini S, Falandysz J, et al. Perfluorooctanesulfonate and related fluorochemicals in human blood from several countries. Environ Sci Technol, 2004, 38: 4489-4495[DOD]

49 Guruge K S, Taniyasu S, Yamashita N, et al. Perfluorinated organic compounds in human blood serum and seminal plasma: A study of urban and rural tea worker populations in Sri Lanka. J Environ Monit, 2005, 7: 371-377 [DOI]

50 Taniyasu S, Kannan K, Horii Y, et al. A Survey of perfluorooctane sulfonate and related perfluorinated organic compounds in water, fish, birds, and humans from Japan. Environ Sci Technol, 2003, 37: 2634-2639[DOI]

51 Inoue K, Okada F, Ito R, et al. Perfluorooctane sulfonate (PFOS) and related perfluorinated compounds in human maternal and cord blood samples: Assessment of PFOS exposure in a susceptible population during pregnancy. Environ Health Perspect, 2004, 112: $1204-1207$

52 Ehresman D J, Froehlich J W, Olsen G W, et al. Comparison of human whole blood, plasma, and serum matrices for the determination of perfluorooctanesulfonate (PFOS), perfluorooctanoate (PFOA), and other fluorochemicals. Environ Res, 2007, 103: 176$184 \underline{[\mathrm{DOI}]}$

53 Apelberg B J, Goldman L R, Calafat A M, et al. Determinants of fetal exposure to polyfluoroalkyl compounds in Baltimore, Maryland. Environ Sci Technol, 2007, 41: 3891-3897[DOI]

54 Calafat A M, Kuklenyik Z, Caudill S P, et al. Perfluorochemicals in pooled serum samples from United States residents in 2001 and 2002. Environ Sci Technol, 2006, 40: 2128-2134[DOI]

55 Falandysz J, Taniyasu S, Gulkowska A, et al. Is fish a major source of fluorinated surfactants and repellents in humans living on the Baltic coast? Environ Sci Technol, 2006, 40: 748 - 751[DOI]

56 Ericson I, Gómez M, Nadal M, et al. Perfluorinated chemicals in blood of residents in Catalonia (Spain) in relation to age and gender: A pilot study. Environ Int, 2007, 33: 616-623 [DOI]

57 Kärrman A, van Bavel B, Järnberg U, et al. Perfluorinated chemicals in relation to other persistent organic pollutants in human blood. Chemosphere, 2006, 64: 1582-1591 [DOI]

58 Yeung L W Y, So M K, Jiang G, et al. Perfluorooctanesulfonate and related fluorochemicals in human blood samples from China. Environ Sci Technol, 2006, 40: 715-720[DOI]

59 Olsen G W, Huang H Y, Helzlsouer K J, et al. Historical comparison of perfluorooctanesulfonate, perfluorooctanoate, and other fluorochemicals in human blood. Environ Health Perspect, 2005, 113: 539-545

60 Calafat A M, Needham L L, Kuklenyik Z, et al. Perfluorinated chemicals in selected residents of the American continent. Chemosphere, 2006, 63: 490-496[DOD]

61 Olsen G W, Church T R, Miller J P, et al. Perfluorooctanesulfonate and other fluorochemicals in the serum of American Red Cross adult blood donors. Environ Health Perspect, 2003, 111: 1892-1901

62 Kuklenyik Z, Reich J A, Tully J S, et al. Automated solid-phase extraction and measurement of perfluorinated organic acids and amides in human serum and milk. Environ Sci Technol, 2004, 38: 3698-3704 $\underline{\text { [DOI] }}$ 
63 Olsen G W, Church T R, Larson E B, et al. Serum concentrations of perfluorooctanesulfonate and other fluorochemicals in an elderly population from Seattle, Washington. Chemosphere, 2004, 54: 1599-1611 [DOI]

64 Calafat A M, Kuklenyik Z, Reidy J A, et al. Serum concentrations of 11 polyfluoroalkyl compounds in the US population: Data from the national health and nutrition examination survey (NHANES) 1999-2000. Environ Sci Technol, 2007, 41: 2237-2242[DOI]

65 Kärrman A, Langlois I, van Bavel B, et al. Identification and pattern of perfluorooctane sulfonate (PFOS) isomers in human serum and plasma. Environ Int, 2007, 33: 782-788[DO]

66 Harada K, Inoue K, Morikawa A, et al. Renal clearance of perfluorooctane sulfonate and perfluorooctanoate in humans and their species-specific excretion. Environ Res, 2005, 99: 253-261[DOI]

67 Darnerud P O, Eriksen G S, Johannesson T, et al. Polybrominated diphenyl ethers: Occurrence, dietary exposure, and toxicology. Environ Health Perspect, 2001, 109: 49-68[DOD]

68 Betts K S. What fate for brominated fire retardants. Environ Sci Technol, 2000, 34: 223A-226A

69 Wang Y W, Jiang G B, Lam P K S, et al. Polybrominated diphenyl ether in the east Asian environment: A critical review. Environ Int, 2007, 33: 963-973 [DOD]

70 Hori S, Akutsu K, Oda H, et al. Development of an analysis method for polybrominated diphenyl ethers and their levels in Japanese human mother's milk. Organohalogen Compd, 2002, 58: 245-248

71 Kazda R, Hajšlová J, Poustka J, et al. Determination of polybrominated diphenyl ethers in human milk samples in the Zzech Republic comparative study of negative chemical ionization mass spectrometry and time-of-flight high resolution mass spectrometry. Anal Chim Acta, 2004, 520: 237-243[DOI]

72 Kalaztzi O I, Martin F L, Thomas G O, et al. Different levels of polybrominated diphenyl ethers (PBDEs) and chlorinated compounds in breast milk from two UK regions. Environ Health Perspect, 2004, 112: 1085-1091

73 Danial L, Maria A, Ioannis A, et al. A preliminary study on PBDEs and HBCD in blood and milk from Mexican women. The Third International Workshop on Brimniated Flame Retardants, 2004, Canada. 483-488

74 Fängström B, Strid A, Grandjean P, et al. A retrospective study of PBDEs and PCBs in human milk from the Faroe Islands. Environ Health, 2005, 14: 4-12

75 Vieth B, Herrmann T, Mielke H, et al. PBDE levels in human milk: The situation in Germany and potential influencing factors - a controlled study. Organohalogen Compd, 2004, 66: 2643-2648

76 Tsydenova O, Sudaryanto A, Kajiwara N, et al. Organohalogen compounds in human breast milk from Republic of Buryatia, Russia. Environ Pollut, 2007, 146: 225-232[DOI]

77 Ingelido, A M, Ballard T, Dellatte E, et al. Polychlorinated biphenyls (PCBs) and polybrominated diphenyl ethers (PBDEs) in milk from Italian women living in Rome and Venice. Chemosphere, 2007, 67: S301 - S306 [DOI]

78 Ryan J J, Patry B. Determination of brominated diphenyl ethers (BDEs) and levels in Canadian human milks. Organohalogen Compd, 2000, 47: 57-60

79 Akutsu K, Kitagawa M, Nakazawa H, et al. Time-trend (1973-2000) of polybrominated diphenyl ethers in Japanese mother's milk. Chemosphere, 2003, 53: 645-654 [DOI]

80 Gill U, Chu I, Ryan J J, et al. Polybrominated diphenyl ethers: Human tissue levels and toxicology. Rev Environ Contam T, 2004, 183: 55 — 97

81 Ryan J J, Patry B. Body burdens and exposure from food for polybrominated diphenyl ethers (BDEs) in Canada. Organohalogen Compd, 2001, 51: 226-229

82 Sjödin A, McGahee E E, Focant J F, et al. Semiautomated high-throughput extraction and cleanup method for the measurement of polybrominated diphenyl ethers and polybrominated and polychlorinated biphenyls in breast milk. Anal Chem, 2004, 76: 4508 - 4514 [DOD]

83 Strandman T, Koistinen J, Vartiainen T. Polybrominated diphenyl ethers (PBDEs) in placenta and human milk. Organohalogen Compd, 2000, 47: 61-64

84 She J W, Holden A, Sharp M, et al. Polybrominated diphenyl ethers (PBDEs) and polychlorinated biphenyl (PCBs) in breast milk from the Pacific Northwest. Chemosphere, 2007, 67: S307-S317 [DOI]

85 Darnerud P O, Atuma S, Aune M, et al. Polybrominated diphenyl ethers (PBDEs) in breast milk from primiparous women in Uppsala county, Sweden. Organohalogen Compd, 1998, 35: 411-414

86 Atuma S, Aune M, Darnerud P O, et al. Polybrominated diphenyl ethers PBDEs in human milk from Sweden. Am Chem Soc Symp Ser, 2001, 773: 235-242

87 Jaraczewska K, Lulek J, Covaci A M, et al. Distribution of polychlorinated biphenyls, organochlorine pesticides and polybrominated diphenyl ethers in human umbilical cord serum, maternal serum and milk from Wielkopolska region, Poland. Sci Total Environ, 2006, 372: $21-31$

88 Toms L M, Harden F A, Symons R K, et al. Polybrominated diphenyl ethers (PBDEs) in human milk from Australia. Chemosphere, 2007, 68: 797-803 [DO]

89 Ohta S, Ishizuka D, Nishimura H, et al. Real situation of contamination by polybrominated diphenyl ethers as flame retardants in 
market fish and mother milk of Japan. Organohalogen Compd, 2000, 47: 218-221

90 Sudaryanto A, Kajiwara N, Tsydenova O, et al. Global Contamination of PBDEs in Human Milk from Asia. Organohalogen Compd, 2005, 67: 1315-1318

91 Päpke O, Bathe L, Bergman A, et al. Determination of PBDEs in human milk from the United States comparison of results from tree laboratories. Organohalogen Compd, 2001, 52: 197-200

92 Eslami B, Koizumi A, Ohta S, et al. Large-scale evaluation of the current level of polybrominated diphenyl ethers (PBDEs) in breast milk from 13 regions of Japan. Chemosphere, 2006, 63: 554-561[DOI]

93 Ryan J J, Patry B, Mills P, et al. Recent trends in levels of brominated diphenyl ethers (BDEs). Organohalogen Compd, 2002, 58: 173 - 176

94 Erdoğrul O, Covaci A, Kurtul N, et al. Levels of organohalogenated persistent pollutants in human milk from Kahramanmaras region, Turkey. Environ Int, 2004, 30: 659-666[DOI]

95 Schecter A, Pavuk M, Päpke O, et al. Polybrominated diphenyl ethers (PBDEs) in US mother's milk. Environ Health Perspect, 2003, 111: 1723-1729

96 So M K, Yamashita N, Taniyasu S, et al. Health risks in infants associated with exposure to perfluorinated compounds in human breast milk from Zhoushan, China. Environ Sci Technol, 2006, 40: 2924-2929 [DOI]

97 Kärrman A, Ericson I, van Bavel B, et al. Exposure of perfluorinated chemicals through lactation: Levels of matched human milk and serum and a temporal trend, 1996-2004, in Sweden. Environ Health Perspect, 2007, 115: 226-230

98 Choi J, Fujimaki S, Kitamura K, et al. Polybrominated dibenzo-p-dioxins, dibenzofurans, and diphenyl ethers in Japanese human adipose tissue. Environ Sci Technol, 2003, 37: 817-821ㅁO]

99 Kunisue T, Takayanagi N, Isobe T, et al. Polybrominated diphenyl ethers and persistent organochlorines in Japanese human adipose tissues. Environ Int, 2007, 33: 1048-1056[DOI]

100 Li Q Q, Loganath A, Chong Y S, et al. Determination and occurrence of polybrominated diphenyl ethers in maternal adipose tissue from inhabitants of Singapore. J Chromatogr B, 2005, 819: 253-257 [DO]

101 Covaci A, de Boer J, Ryan J J, et al. Distribution of organobrominated and organchlorinated contaminants in Belgian human adipose tissue. Environ Res A, 2002, 88: 210-218 $\underline{\text { [DOD] }}$

102 Meironyté Guvenius D, Bergman A, Norén K. Polybrominated diphenyl ethers in Swedish human liver and adipose tissue. Arch Environ Contam Toxicol, 2001, 40: 564-570[DOI]

103 Haglund P S, Zook D R, Buser H R, et al. Identification and quantification of polybrominated diphenyl ethers and methoxy-polybrominated diphenyl ethers in Baltic biota. Environ Sci Technol, 1997, 31: 3281-3287[DOI]

104 Strandman T, Koistinen J, Kiviranta H, et al. Levels of some polybrominated diphenyl ethers (PBDEs) in fish and human adipose tissue in Finland. Organohalogen Compd, 1999, 40: 355-358

105 Smeds A, Saukko P. Brominated flame retardants and phenolic endocrine disrupters in Finnish human adipose tissue. Chemosphere, 2003, 53: 1123-1130[DOI]

106 Meneses M, Wingfors H, Schuhmacher M, et al. Polybrominated diphenyl ethers detected in human adipose tissue from Spain. Chemosphere, 1999, 39: 2271-2278[DOI]

107 Fernandez M F, Araque P, Kiviranta H, et al. PBDEs and PBBs in the adipose tissue of women from Spain. Chemosphere, 2007, 66: $377-383$ [DOI]

108 Crhova S, Cerna M, Grabic R, et al. Polybrominated flame retardants in human adipose tissue in Czech Republic inhabitants: The pilot study. Organohalogen Compd, 2002, 58: 241-244

109 She J, Petreas M, Winkler J, et al. PBDEs in the San Francisco Bay area: Measurements in harbor seal and human breast adipose tissue. Chemosphere, 2002, 46: 697-707 [DOI]

110 Johnson-Restrepo B, Kannan K, Rapaport D P, et al. Polybrominated diphenyl ethers and polychlorinated biphenyls in human adipose tissue from New York. Environ Sci Technol, 2005, 39: 5177-5182[DOI]

$111 \mathrm{Qu} \mathrm{W}$ Y, Bi X H, Sheng G Y, et al. Exposure to polybrominated diphenyl ethers among workers at an electronic waste dismantling region in Guangdong, China. Environ Int, 2007, 33: 1029-1034[DOI]

112 Thuresson K, Bergman A, Jakobsson K. Occupational exposure to commercial decabromodiphenyl ether in workers manufacturing or handling flame-retarded rubber. Environ Sci Technol, 2005, 39: 1980-1986[DO]

113 Thuresson K, Bergman A, Rothenbacher K, et al. Polybrominated diphenyl ether exposure to electronics recycling workers-a follow up study. Chemosphere, 2006, 64: 1855-1861 $\underline{\text { DOI] }}$

114 Schecter A, Harris T R, Päpke O, et al. Polybrominated diphenyl ether (PBDE) levels in the blood of pure vegetarians (vegans). Toxicol Environ Chem, 2006, 88: 107-112[DO]

115 Meng X Z, Zeng E Y, Yu L P, et al. Assessment of human exposure to polybrominated diphenyl ethers in China via fish consumption and inhalation. Environ Sci Technol, 2007, 41: 4882-4887 [DO]] 